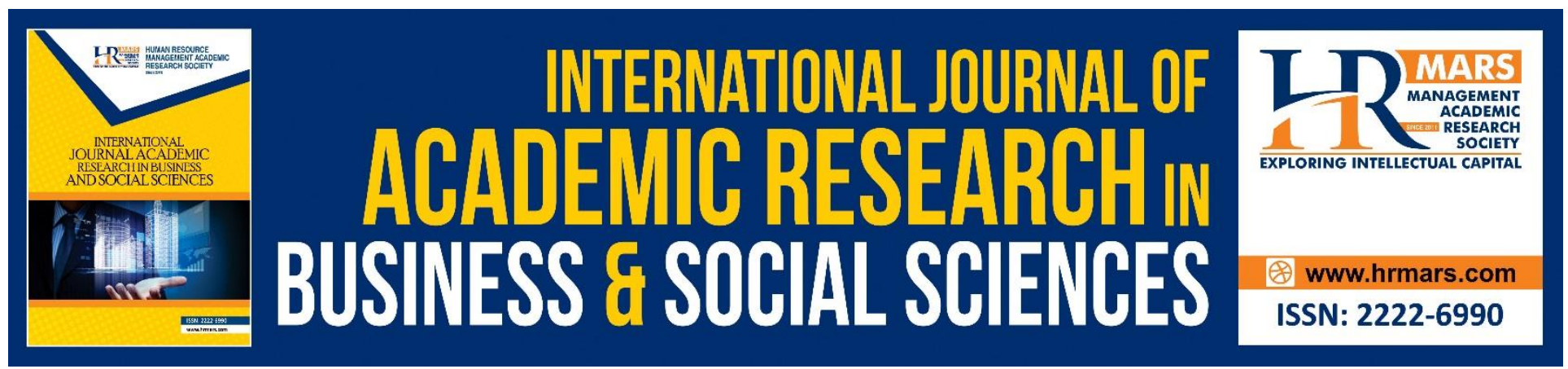

\title{
The Enabling Conditions Necessary for Effective Online Mentoring: A Proposed Model
}

\author{
Nadine Oosthuizen, Sandra Perks
}

To Link this Article: http://dx.doi.org/10.6007/IJARBSS/v9-i6/5975

DOI: $10.6007 /$ IJARBSS/v9-i6/5975

Received: 14 April 2019, Revised: 21 May 2019, Accepted: 01 June 2019

Published Online: 22 June 2019

In-Text Citation: (Oosthuizen \& Perks, 2019)

To Cite this Article: Oosthuizen, N., \& Perks, S. (2019). The Enabling Conditions Necessary for Effective Online Mentoring: A Proposed Model. International Journal of Academic Research in Business and Social Sciences, 9(6), 600-612.

Copyright: (C) 2019 The Author(s)

Published by Human Resource Management Academic Research Society (www.hrmars.com)

This article is published under the Creative Commons Attribution (CC BY 4.0) license. Anyone may reproduce, distribute, translate and create derivative works of this article (for both commercial and non-commercial purposes), subject to full attribution to the original publication and authors. The full terms of this license may be seen at: http://creativecommons.org/licences/by/4.0/legalcode

Vol. 9, No. 6, 2019, Pg. 600 - 612

Full Terms \& Conditions of access and use can be found at http://hrmars.com/index.php/pages/detail/publication-ethics 


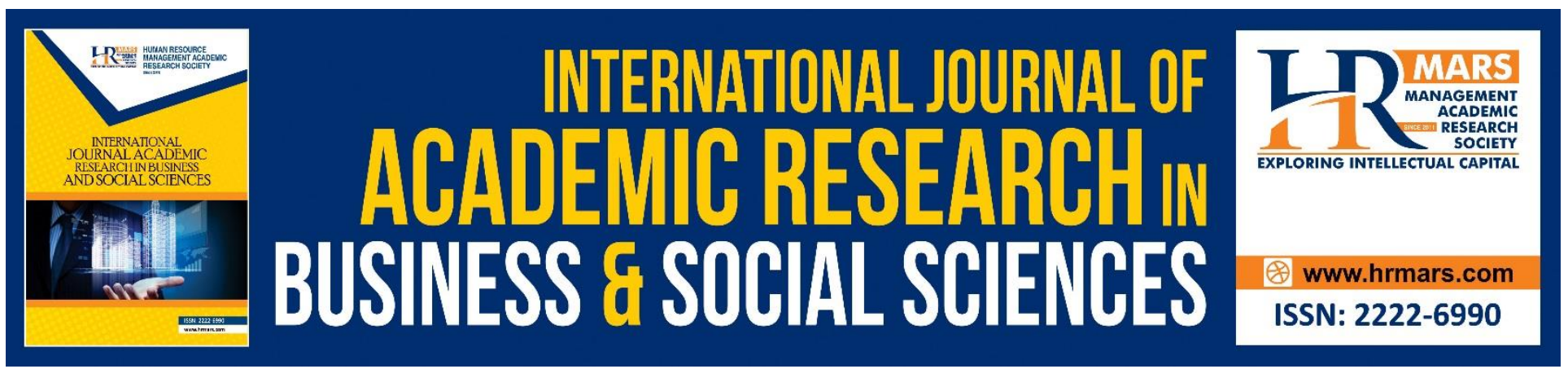

\title{
The Enabling Conditions Necessary for Effective Online Mentoring: A Proposed Model
}

\author{
Dr. Nadine Oosthuizen, Prof. Sandra Perks \\ Nelson Mandela University, South Africa
}

\begin{abstract}
Online mentoring offers several benefits to stereotyped individuals and those from marginalized groups as it combines conventional mentoring approaches with new technology and provides wider access to a pool of mentors. The aim of this paper was to develop and validate a hypothesized model of the enabling conditions necessary for effective female online mentoring. A positivistic quantitative research methodology was followed by collecting data with a structured self-administered online questionnaire using convenience and snowball sampling. A final sample of 63 respondents in South African were obtained. An Exploratory Factor Analysis was applied to extract the valid constructs and Cronbach's alpha coefficients calculated to confirm reliability of the measuring scales. The enabling conditions for effective online mentoring are infrastructure readiness, consideration of demographic matching preference, the characteristics of the mentor; the communication process followed; the perception of the mentoring pair about online mentoring and to develop an online relationship. The validated model and measuring instrument can be used by researchers for further testing or by institutions wishing to implement an effective online mentoring program.
\end{abstract}

\section{Introduction}

Females remain conspicuously marginalized in executive and decision-making positions, regardless of the existence of equal opportunity and affirmative action policies in developing countries Republic of South Africa, 2015). Research in the domain of females in management, ascribes the global underrepresentation of females at executive level to an array of barriers impeding females' development beyond an apparent glass ceiling (Maürtin-Cairncross, 2009; Daft, 2010; Howe-Walsh, Turnbull, Papavasileiou \& Bozionelos, 2016). As occupation and supervisory structures improve, the conventional model of mentoring, in which a high-ranking organisational member teaches a junior employee how to perform his or her role face-to-face, is changing (Headlam-Wells, Gosland \& Craig, 2005, p.445; Leppisaari \& Tenhunen, 2009, p.204; Rockwell, Leck \& Elliott, 2013, p.2). Research has confirmed that females who have a mentor perform at superior levels as they acquire cogitated power, advice and the privilege to use necessary resources and senior managers through their mentorship relationship (Neal, Boatman \& Miller, 2013, p.3). A primary barrier to females' success in both the business and entrepreneurship field has been access to mentoring (Kyrgidou \& Petridou, 
2013, p.549). In addition, one of the most prominent issues identified is a dearth of female mentors with whom females can identify (Block \& Tietjen-Smith, 2016, p.306).

With the revolution in technology, online mentoring provides access to an alternative way of mentoring. Certain advantages present themselves when online mentoring is compared with conventional mentoring such as the equalisation of status, reduced costs, greater access, decreased emphasis on demographics, and a record of interactions (Leck \& Wood, 2013, p.104). Online mentoring allows mentees from remote areas or with problems of mobility, to access mentors with the expertise they seek provided they have internet access (Leck, Elliott, Bourgeois \& Kemp, 2014, p.15). Face-to-face interactions of conventional mentoring may involve the distraction of visual clues and aspects of setting, context and atmosphere that may hamper communication. Since online mentoring is faceless, it reduces potential negative stereotyping and discrimination (Martin, 2012, p.223.). Cross-gender mentoring relationships are less likely to be misinterpreted with the physical separation of mentor and mentee (Leck et al., 2014, p.17). Online mentoring is, therefore, especially beneficial for stereotyped individuals and those from marginalised groups such as females (Leck \& Wood, 2013, p.104).

There is limited empirical research examining the effectiveness of online mentoring programmes (Kyrgidou \& Petridou, 2013, p.552; Nchindila, 2007, p.12). Mentoring programmes for females are clearly desirable, but the question that still needs to be answered is what conditions must exist for an enabling online mentoring environment to ensure effective female career advancement. With South Africa being a developing country, online mentoring is even more crucial due to gender stereotyping and for the development of previously disadvantaged individuals. The aim of this paper is two-fold - to develop and validate a hypothesised model of the enabling conditions necessary for effective online mentoring. Although only a South African sample participated in the survey, the content of this paper can be extended to any developing country and within the context of any specific business industry.

The remainder of the paper will present a brief literature overview on enabling conditions necessary for effective online mentoring, the hypothesized model of the enabling conditions necessary for effective online mentoring, and the research methodology followed to validate the proposed model. This will be followed by the results, limitations and future research, conclusions and recommendations for those institutions wishing to implement a mentoring programme to enhance female employees' achievements.

\section{Literature Overview on Enabling Conditions for Effective Online Mentoring}

Online mentoring refers to technologically-mediated mentoring between the mentor and mentee, characterised by its non-face-to-face nature and can be computer or mobile based (Stewart \& McLoughlin, 2007). This paper explores seven mentoring enablers deemed to be the most prominent in literature as necessary for effective online mentoring.

The necessary technology infrastructure available is important for effective online mentoring (Rowland, 2012, p.3). Technology infrastructure is not just about the availability of a user-friendly 
communication interaction channel for online mentoring, but to have access to a computer or mobile device and include a quality administrative and technical support system for the storage, retrieval, and maintenance of information and recovery of data, while also providing for fast internet and unreserved email access (Panopoulos \& Sarri, 2013, p.223; Wong \& Premkumar, 2007, p.6; Elkin \& Elkin, 2008, p.24).

Some authors are of the opinion that the matching preference of the online mentoring pair should be considered (De Janasz \& Godshalk, 2013, p.748; Bullock \& Ferrier-Kerr, 2014, p.81). Matching preferences require taking into consideration age, gender, ethnic affiliation, and language spoken of both the mentee and mentor (DiRenzo, Linnehan, Shao \& Rosenberg, 2010, p.302). The mentor's extent of previous mentoring experience is also regarded important together with educational background, work and career experience, as well as leadership style and personality match (Rockwell et al., 2013, p.8; Leck et al., 2014, p.1; DiRenzo et al., 2010, p.302; Sphigelman \& Gill, 2012, p.464).

To select an appropriate communication process to engage in online mentoring is important and denotes choosing an online communication medium with preferably multiple contact methods allowing oral or written contact to make it easier for the mentoring pair to convey a logical, detailed clear message on a specific topic, or range of topics (Leck \& Wood, 2013, p.104; Wong \& Premkumar, 2007, p.2). The message must be conveyed in a simple way allowing for expression of feelings to avoid misinterpretation or allowing elaboration on the meaning of words, if necessary (Rockwell et al., 2013, p.2).

Logistics to engage in online mentoring is important as it necessitates the coordination of bringing into contact available mentors and mentees using the same interaction communication method while taking into consideration available meeting times and time zone differences (De Janasz \& Godshalk, 2013, p.748; Keengwe \& Blankson, 2013, p.263). To enable effective online mentoring the frequency of interaction, response speed and intended duration of the online mentoring programme should be pre-determined (Rockwell et al., 2013, p.7; Wood, 2014, p.12; Homitz \& Berge, 2008, p.329).

Several authors topics (Leck \& Wood, 2013, p.105; DiRenzo et al., 2010, p.292; Kent, Green. \& Feldman, 2015, p.118.; Blickle, Schneider, Meurs \& Perrewé, 2010, p.1902) confirmed that the perceptions of the mentoring pair of the challenges associated with, the complexity of the online mentoring process, how they perceive cultural differences, their similarity in attitude, values and beliefs and benefits can influence how quickly they can develop a close relationship and an effective outcome.

The ability of the mentoring pair to develop an online relationship is important because if they relate personally to each other, mutual trust can be build (Bullock \& Ferrier-Kerr, 2014, p.82; Williams \& Kim, 2011, p.85). The development of an online mentoring pair relationship can be fast-tracked through a structured, goal-orientated, two-way information exchange based on set relationship 
INTERNATIONAL JOURNAL OF ACADEMIC RESEARCH IN BUSINESS AND SOCIAL SCIENCES Vol. 9, No. 6, June, 2019, E-ISSN: 2222-6990 C 2019 HRMARS

boundaries, the content of the interactions and offering emotional support (Williams, Sunderman \& Kim, 2012, p.113; Beddoes-Jones \& Miller, 2006, p.54).

The readiness of the mentoring pair to engage in online mentoring lies in their ability to communicate online by being adequately computer literate and able to use online technology (Leck \& Wood 2013, p.105; Wood, 2014, p.13). The willingness of mentees to persevere and implement changes to fasttrack their future career is also an indication of their openness towards the mentoring process (Rowland, 2012, p.3).

An enabling mentoring environment will make the mentee feel fulfilled, whether through satisfaction of self-development needs, improved self-confidence; or increase in interpersonal and workplace skills (Kyrgidou \& Petridou, 2013, p.558; Clutterbuck \& Haddock-Miller, 2016, p.9). Effective mentoring can lead to innovative thinking, work life control, increased business performance and professional network connections that increase real-world knowledge for business applications and ultimately results in fulfilled career path dreams (Block \& Tietjen-Smith, 2016, p.306; Leck. \& Wood 2013, p.101,102,107; Petridou, Sarri \& Kyrgidou, 2009, p.294).

Hypothesized Model of Enabling Conditions Necessary for Effective Online Mentoring Based on the preceding literature review, the following hypothesized model was developed.

Figure 1: Proposed Hypothesized Model of Enabling Conditions Necessary for Effective Online Mentoring

\section{Enabling conditions}

Technology infrastructure

Matching preference

Communication process

Logistics

Mentoring pair perceptions

Mentoring pair relationship

Mentoring pair readiness

The research methodology followed to validate the proposed model is described below.

\section{Research Methodology}

The study followed the positivistic quantitative methodology to collect and analyze the numerical data and testing of hypotheses data for the study (Bryman \& Bell, 2014, p.62). Females employed or owning small businesses in South Africa SA) that have been involved in conventional mentoring as well as mentors female and male) that have provided conventional mentoring constituted the population. No sampling frame was available as the few SA institutions that offer online mentoring 
either not keep a formal database or would not make their database of their mentors and mentees available because of confidentiality agreements. Limited access to a database from a well-known South African female conventional mentoring institution with a high success rate in mentoring, was obtained. For this reason, the criterion for inclusion in the sample was that participants must have been involved at some stage, in conventional mentoring - either as a mentor or as a mentee, as reflected in the qualifying question in the online questionnaire. Information was canvassed from both female mentees, as well as male- and female mentors. Male mentors were included in the study as this institution utilizes both female and male mentors due to the shortage of available female mentors in SA. As two mentors were allocated for each mentee, they were also deemed able to provide further insight into the enabling conditions necessary for effective online female mentoring.

Due to the limited access, both convenience and snow ball sampling was employed. The structured, self-administered questionnaire was emailed with a covering letter containing a link to the online web-based questionnaire to those respondents on the limited database with a request to forward the invitation to participate in the online survey to other mentees or mentors that provided mentoring for this institution. A total of 100 South African respondents were invited to participate in the online survey. The final pilot sample comprised 63 respondents that were willing to complete the questionnaire.

The Information and Communication Technology ITC) Department at the Nelson Mandela University assisted with the creation of the online Lime Survey that facilitates the administering and automatic collection and collation of survey responses. The self-administered questionnaire consisted of a cover letter and three sections. The covering letter provided details regarding the purpose of the study and the type of information sought. Aspects such as confidentiality and anonymity were addressed. Likert scale questions were designed for Section A 65 statements) and B 13 statements) to examine how important the respondents regard the enabling conditions for online mentoring as well as what they regard as effective online mentoring outcomes. The Likert scale had a five-point scale varying from strongly disagree (1) to strongly agree (). Section C solicited the generic demographic information from all the respondents.

The statistical programme STATISTICA was employed to analyse the captured data. An Exploratory Factor Analysis EFA) was applied to the data to extract the valid constructs. Eigenvalues were calculated to determine which of the extracted constructs were to be retained, with those extracts with an Eigenvalue above 1.0 being retained (Solanas, Manolov, Leiva \& Richards, 2011, p.34).

To confirm construct validity, factor loadings of greater than 0.5 , as well as those that loaded onto one construct, were viewed as significant (Zikmund, Babin, Carr \& Griffen, 2009, p.594). All items with cross-loadings were deleted in the factor matrix and only constructs with three or more items were considered valid (Osborne, 2008, p.89). The retained constructs were subsequently assessed for reliability by calculating the Cronbach's alpha coefficients $\alpha$ ), and an $\alpha>0.7$ was deemed to be acceptable (George \& Mallery, 2003, p.231). 
INTERNATIONAL JOURNAL OF ACADEMIC RESEARCH IN BUSINESS AND SOCIAL SCIENCES Vol. 9, No. 6, June, 2019, E-ISSN: 2222-6990 @ 2019 HRMARS

Based on the results of the EFA and reliability tests, some of the constructs required renaming due to the re-grouping of items. The final results of the pilot study provides therefore a validated model and measuring instrument that researchers can use for further testing or as recommendations for institutions regarding what to pay attention to when implementing an online mentoring program for females for effective online mentoring outcomes.

\section{Validation of the Measuring Instrument}

The EFA for the extraction of constructs with Eigenvalues above one revealed six independent- and one dependent constructs. The items in the logistics and mentoring pair readiness constructs did not have factor loadings above 0.5 , or loaded onto other constructs. Based on the grouping of items within the constructs, some constructs required renaming. Technology infrastructure was renamed to infrastructure readiness. Matching preference loaded as two constructs and these constructs were renamed to demographic matching preference and mentor characteristics to accurately define the dimensions of the constructs. Based on the principle component extraction the constructs explained a cumulative $40,54 \%$ of the variance in the data. Table 1 provides a summary of the results.

Table 1: $\quad$ Summary of the results

\begin{tabular}{|l|c|c|c|c|c|}
\hline Factors & $\begin{array}{c}\text { Eigen } \\
\text { value }\end{array}$ & $\begin{array}{c}\text { Number } \\
\text { of items } \\
\text { retained }\end{array}$ & $\begin{array}{c}\text { Minimum } \\
\text { factor } \\
\text { loading }\end{array}$ & $\begin{array}{c}\text { Maximum } \\
\text { factor } \\
\text { loading }\end{array}$ & $\begin{array}{c}\text { Cronbach's } \\
\text { alpha }\end{array}$ \\
\hline Effective online mentoring outcomes & 15.7 & 10 & 0.537 & 0.750 & 0.884 \\
\hline Infrastructure readiness & 3.6 & 6 & 0.519 & 0.836 & 0.842 \\
\hline Demographic matching preference & 3.3 & 3 & 0.665 & 0.754 & 0.781 \\
\hline Mentor characteristics & 4.2 & 5 & 0.531 & 0.730 & 0.752 \\
\hline Communication process & 4.8 & 6 & 0.521 & 0.667 & 0.773 \\
\hline Mentoring pair perceptions & 3.1 & 6 & 0.547 & 0.688 & 0.808 \\
\hline Mentoring pair relationship & 4 & 5 & 0.552 & 0.663 & 0.704 \\
\hline
\end{tabular}

As can be seen in Table 1, the Eigen values ranged from 3.1 to 15.7. A total of 31 items were retained of the 65 items intended to measure the independent variables. Thirty two items did not have factor loadings above 0.5 , while two items cross-loaded onto other factors and were thus disregarded. Factor loadings reported for the valid factors ranged from 0.519 to 0.836 . Furthermore, all Cronbach's alpha coefficients exceeded the cut-off point of 0.70 , thereby providing sufficient evidence of good reliability for the scales.

\section{Validated Hypothesized Model}

Based on the outcome of the EFA and Cronbach alpha coefficients, Figure 2 indicates the validated hypothesized model of the enabling conditions for effective online mentoring. 
INTERNATIONAL JOURNAL OF ACADEMIC RESEARCH IN BUSINESS AND SOCIAL SCIENCES

Vol. 9, No. 6, June, 2019, E-ISSN: 2222-6990 @ 2019 HRMARS

Figure 2: The Validated Hypothesized Model of the Enabling Conditions for Effective Online Mentoring

\section{Enabling Conditions}

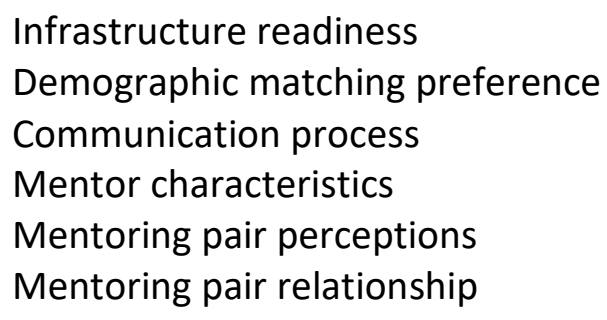

Many of the findings in this article has been confirmed in literature. Creating and maintaining an online mentoring program requires sufficient resources, not only for the development of a technical infrastructure, but also for the labour-intensive work of programme co-ordination, training and ongoing communications with mentors and mentees (Mueller, 2004, p.59). Technology training ensures that online mentors and mentees are at ease with the technologies utilized by the programme as an online mentoring relationship requires a definite level of computer and mobile technology literacy, and internet knowledge otherwise communication will be flawed (Keengwe \& Blankson, 2013, p.6; Williams \& Kim, 2011, p.89).

Demographic variables like gender, culture and racial issues play a part in online mentoring relationships, and may pose a challenge to the matching of parties (Wong \& Premkumar, 2007, p.7; DiRenzo et al., 2010, p.302). Research reveals that females and other minorities face significant challenges with respect to mentoring in the workplace and, because of that, mentees prefer to be, and benefit from, being mentored by someone similar in gender, race and age (Leck et al., 2014, p.1).

Based on a previous study, it was found that the use of both synchronous and asynchronous (both parties interact at different times) communication tools are recommended for effective dialogue (Blickle et al., 2010, p.1902). The use of multiple methods of contact in communicating as a means in which to increase comfort levels and learn about one another in multiple contexts is recommended as it can facilitate the success of the online mentoring relationship and must be kept in mind during pre-planning (Ensher, Heun \& Blanchard, 2003, p.284). Setting a communication plan at the beginning of the programme, and regular contact between mentoring parties is essential for the development of a successful relationship as it necessitates that the parties establish frequent times to communicate (Bullock \& Ferrier-Kerr, 2014, p.80; Stokes, Garrett-Harris \& Hunt, 2003, p.12).

It is imperative that, when selecting mentors, consideration be given to both the expertise and the respective skills that the mentors possess since the effectiveness of mentorship depends on knowledge, attitude and competence (Rankhumise, 2013, p.375). It is further beneficial to use mentors who have had previous experience in business mentoring, in particular for entrepreneur 
INTERNATIONAL JOURNAL OF ACADEMIC RESEARCH IN BUSINESS AND SOCIAL SCIENCES Vol. 9, No. 6, June, 2019, E-ISSN: 2222-6990 (C) 2019 HRMARS

mentees as they prefer an applied and experiential learning experience (St Jean \& Audet, 2012, p.4, 12).

It was confirmed by several authors (Leck \& Wood, 2013, p.105; DiRenzo et al., 2010, p.292) that the perception of the mentoring pair of the challenges associated with, and the complexity of, the online mentoring process influences the effectiveness thereof. If the online mentoring process is perceived as not challenging and regarded as beneficial to the mentee, the mentee will gain self-confidence to pursue her dream and build her morale, which will ultimately lead to an improved performance in the workplace and achieving career goals (Page, 2014; Potgieter, 2011, p.13).

Establishing a good mentoring relationship in terms of rapport and trust is perceived as a vital component in the success of an online mentoring relationship (Leck \& Wood, 2013, p.107; Stokes et al., 2003, p.12). As noted in literature, perceived similarity in values, attitude and beliefs between the mentor and mentee may have a positive influence on creating a trusting or prolonged mentoring relationship (Ensher et al., 2003, p.268).

\section{Limitations and Future Research Suggestions}

A few limitations should be considered when making interpretations and conclusions relating to the findings of this study. The findings in this study are based on the mentoring perceptions and experiences of only 63 mentors and mentees involved with conventional mentoring in South Africa which is not necessarily representative of the larger population set. A larger sample may have provided different results. As all participants were from South Africa, a sample which include global respondents might have rendered different results. Despite these limitations, the findings of this study contribute to the body of knowledge of enabling conditions necessary for effective online mentoring in SA. Online mentoring is an under-researched field, not just in SA, but globally.

Based on the validated hypothesized model, it is suggested that the following hypotheses be tested with a larger global sample size:

$\mathrm{H}_{1}$ : The infrastructure readiness to engage in online mentoring influences effective mentoring outcomes.

$\mathrm{H}_{2}$ : The consideration of demographic matching preferences of the online mentoring pair influences effective mentoring outcomes.

$\mathrm{H}_{3}$ : The characteristics of the mentor necessary for engaging in online mentoring influences effective mentoring outcomes.

$\mathrm{H}_{4}$ : The communication process followed to engage in online mentoring influences effective mentoring outcomes.

$\mathrm{H}_{5}$ : The perception of the mentoring pair about online mentoring influences effective mentoring outcomes.

$\mathrm{H}_{6}$ : The ability of the mentoring pair to meet the requirements necessary to develop a relationship during online mentoring influences effective mentoring outcomes.

In addition, promising future research possibilities exist such as: 
- Exploring further the role of supportive technology and infrastructure necessary for effective online mentoring platforms in a quantitative study;

- Explore the enabling conditions specific to small business online mentoring;

- Explore the enabling conditions specific to corporate employee online mentoring.

\section{Conclusions and Significance of the Research}

Although the importance of conventional mentoring has been recognized globally, however, due to family commitments, females may not always be able to fit into the structured time schedule of conventional mentoring. For this reason, online mentoring can provide females, which would otherwise not be able to access mentoring, a chance to do so. It is clear that with access to online mentoring, females can use this support to break the glass ceiling for career advancement. The benefits of online mentoring are considerable, whether for personal gain, career advancement, to fast-track a start-up or grow a small business. However, the perceptions of female mentees regarding the similarity of their values, attitude and beliefs compared to the mentor plays a role in the achievements of the female mentee in the workplace, whether for personal reasons such as building self-confidence, morale or to take control of her life, or for career advancement or growing her small business.

This research is important because it built a body of knowledge by identifying the conditions necessary for online mentoring globally, as well as in South Africa. A proposed hypothesized model was developed and validated through empirical testing on a pilot sample showing the enabling conditions necessary for effective online mentoring for females. A validated measuring instrument was developed which could be made available for further testing in other development countries. It could further be used in developed countries to compare the similarities and differences in enabling conditions necessary for effective online mentoring of females. The results of the validated model could provide guidance to institutions wishing to implement online mentoring on what is regarded important to ensure effective online mentoring.

\section{References}

Beddoes-Jones, F., \& Miller, J. (2006). Virtual mentoring: Can the principle of cognitive pairing increase its effectiveness? International Journal of Evidence Based Coaching and Mentoring, 4(2), 54-60. Retrieved from https://radar.brookes.ac.uk/radar/items/6da67d83-5539-4e71bb7c-017356b3869e/1/.

Blickle G., Schneider P. B., Meurs J. A., \& Perrewé, P. L. (2010). Antecedents and consequences of perceived barriers to obtaining mentoring: A longitudinal investigation. Journal of Applied Social Psychology, 40(8), 1897-1920. doi: 10.1111/j.1559-1816.2010.00644.

Block, B. A., \& Tietjen-Smith, T. (2016). The case for women mentoring women. doi: 10.1080/00336297.2016.1190285.

Bryman, A., \& Bell, E. (2014). Research methodology. South Africa. Cape Town: Oxford University Press.

Bullock, T., \& Ferrier-Kerr, J. (2014). The potential of e-coaching and e-mentoring: Making a case for the introduction of sustainable e-Coaching and e-Mentoring programmes in New Zealand 
INTERNATIONAL JOURNAL OF ACADEMIC RESEARCH IN BUSINESS AND SOCIAL SCIENCES Vol. 9, No. 6, June, 2019, E-ISSN: 2222-6990 @ 2019 HRMARS

schools. New Zealand Journal of Teachers' Work, 11(1), 77-92. Retrieved from http://www.teacherswork.ac.nz/journal/volume11_issue1/bullock.pdf.

Clutterbuck, D., \& Haddock-Miller, J. (2016). Empowering women, broadening horizons: An independent evaluation of the Mentoring Women in Business programme. Retrieved from http://www.cherieblairfoundation.org/wp-content/uploads/2016/06/Empowering-WomenBroadening-Horizons.pdf.

Daft, R. L. (2010). New era of management. $9^{\text {th }}$ Edition. Canada: South Western.

De Janasz, S., \& Godshalk, V. M. (2013). The role of e-mentoring in protégés learning and satisfaction. Group and Organization Management, 38(6), 743-774. doi/10.1177/1059601113511296.

DiRenzo, M. S., Linnehan, F., Shao, P., \& Rosenberg, W. L. (2010). A moderated mediation model of e-mentoring. Journal of Vocational Behavior, 76, 292-305. doi: 10.1016/j.jvb.2009.10.003.

Elkin, J., \& Elkin, G. (2008). E-mentoring: improving mentoring to reduce expatriate failure. Oxford Business and Economics Conference Program. United Kingdom: Oxford.

Ensher, E. A., Heun, C., \& Blanchard, A. (2003). Online mentoring and computer-mediated communication: New directions in research. Journal of Vocational Behavior, 63, 264-288. doi: 10.1016/S0001-8791(03)00044-7.

George, D., \& Mallery, P. (2003). SPSS for Windows step by step: A simple guide and reference. $4^{\text {th }}$ Edition. Boston: Allyn \& Bacon.

Headlam-Wells, J., Gosland, J., \& Craig, J. (2005). There's magic in the web: E-mentoring for women's career development. Career Development International,10(6/7), 444-459. doi: $10.1108 / 13620430510620548$.

Homitz, D. H., \& Berge, Z. L. (2008). Using e-mentoring to sustain distance training and education. The Learning Organization,15(4), 326-335. doi: 10.1108/09696470810879574.

Howe-Walsh, L., Turnbull, S., Papavasileiou, E., \& Bozionelos, N. (2016). The influence of motherhood on STEM women academics' perceptions of organizational support, mentoring and networking. doi: 10.18738/awl.v36i0.21.

Keengwe, J., \& Blankson, L. (2013). Virtual mentoring for teachers: Online professional development practices. Pennsylvania: IGI Global Publishing.

Kent, A. M., Green, A. M., \& Feldman, P. (2015). The road less traveled - crossing gender and racial lines in comprehensive mentoring. International Journal of Educational Research, 72, 116128. doi :10.1016/j.ijer.2015.06.003.

Kyrgidou, L. P., \& Petridou, E. (2013). Developing women entrepreneurs' knowledge, skills and attitudes through electronic mentoring support. Journal of Small Business and Enterprise Development, 20(3), 548-566. doi: 10.1108/JSBED-04-2013-0061.

Leck, J. D., \& Wood, P. M. (2013). Forming trust in e-mentoring: A research agenda. American Journal of Industrial and Business Management, 3, 101-109. doi:10.4236/ajibm.2013.31013.

Leck, J. D., Elliott, C., Bourgeois, E., \& Kemp, K. (2014). Mentoring a diverse workforce knowledge synthesis grant - final report. Working Paper 2014.01. Canada, University of Ottawa: Telfer School of Management. Retrieved from https://ruor.uottawa.ca/bitstream/10393/30698/1/TelferSchool_WP-2014-

01_Leck_Elliott_Bourgeois_Kemp.pdf. 
INTERNATIONAL JOURNAL OF ACADEMIC RESEARCH IN BUSINESS AND SOCIAL SCIENCES Vol. 9, No. 6, June, 2019, E-ISSN: 2222-6990 @ 2019 HRMARS

Leppisaari, I., \& Tenhunen, M. L. (2009). Searching for e-mentoring practices for SME staff development. Journal of Service Business, 3, 189-207. doi: 10.1007/s11628-008-0060-4.

Martin, C. (2012). Promoting the entrepreneurship using a blended learning approach. Conference proceedings of "eLearning and Software for Education". The $8^{\text {th }}$ International Scientific Conference eLearning and Software for Education, 26-27 April, Romania, Bucharest. doi: 10.5682/2066-026X-12-035.

Maürtin-Cairncross, A. (2009). A still-chilly climate: Experiences of women in leadership positions in South African Higher Education. Association of American Colleges. Volume 38(1). Retrieved from http://www.aacu.org/ocww/volume38_1/global.cfm.

Mueller, S. (2004). Electronic mentoring as an example for the use of information and communications technology in engineering education. European Journal of Engineering Education, 29(1), 53-63. doi: 10.1080/0304379032000129304.

Nchindila, B. M. (2007). Conditions for successful online mentoring. Submitted in fulfilment of the requirements for the degree of Master of Arts. Pretoria: University of South Africa. Retrieved from http://uir.unisa.ac.za/bitstream/handle/10500/1701/dissertation.pdf.

Neal, S., Boatman, J., \& Miller, L. (2013). Women as mentors: Does she or doesn't she? A global study of businesswomen and mentoring. Pittsburgh, Pennsylvania: Development Dimensions International.

Osborne, J. W. (2008). Best practices in quantitative methods. California: Sage Publication.

Page, M. (2014). What are the benefits of mentoring? Retrieved from http://www. michaelpage.com.au/advice/management-advice/leadership/what-are-benefits-mentoring.

Panopoulos, A. P., \& Sarri, K. (2013). E-mentoring: The adoption process and innovation challenge. International Journal of Information Management, 33, 217-226. doi; 10.1016/j.ijinfomgt.2012.10.003.

Petridou, E., Sarri, A., \& Kyrgidou, L. P. (2009). Entrepreneurship in higher educational institutions: the gender dimension. Gender in Management: An International Journal, 24(4), 286-309. doi: 10.1108/17542410910961569.

Potgieter, D. (2011). Mentoring as a strategy to develop leadership potential of female employees. Thesis submitted in fulfilment of the requirements for the degree Magister Technologiae in the Faculty of Business Management and Economic Sciences. Nelson Mandela Metropolitan University: Port Elizabeth. Retrieved from http://hdl.handle.net/10948/1472.

Rankhumise, E. M. (2013) Mentoring as an enhancement to career success of protégés. Journal of Public Administration, 48(2), 369-380. Retrieved from

https://hdl.handle.net/10520/EJC140009.

Republic of South Africa. (2015). The status of women in the South African economy. Retrieved from http://www.gov.za/sites/www.gov.za/files/Status_of_women_in_SA_economy.pdf.

Rockwell, B. V., Leck, J. D., \& Elliott, C. J. (2013). Can e-mentoring take the "gender" out of mentoring? Journal of Psychosocial Research on Cyberspace, 7(2), 2-5. doi: 10.5817/CP2013-2-5.

Rowland, K. N. (2012). E-mentoring: an innovative twist to traditional mentoring. Journal of Technology Management and Innovation, 7(1), 1-8. doi: 10.4067/S071827242012000100015. 
INTERNATIONAL JOURNAL OF ACADEMIC RESEARCH IN BUSINESS AND SOCIAL SCIENCES

Vol. 9, No. 6, June, 2019, E-ISSN: 2222-6990 (C) 2019 HRMARS

Sarri, K. (2011). Mentoring female entrepreneurs: a mentors' training intervention evaluation. Journal of Industrial Training, 35(7), 721-741. doi.: 10.1108/03090591111160814.

St Jean, E., \& Audet, J. (2012). The role of mentoring in the learning development of the novice entrepreneur. International Entrepreneurship and Management Journal, 8, 19-140. doi: 10.1007/s11365-009-0130-7.

Solanas, A., Manolov, R., Leiva, D., \& Richards, M. M. (2011). Retaining principal components for discrete variables. Journal of Psychology, 41(3), 33-50. Retrieved from https://www.researchgate.net/publication/277107415_Retaining_principal_components_fo r_discrete_variables.

Sphigelman, C. N., \& Gill, C. J. (2012). The characteristics of unsuccessful e-mentoring relationships for youth with disabilities. Qualitative Health Research, 23(4), 463-475. doi: $10.1177 / 1049732312469115$.

Stewart, S., \& McLoughlin, C. (2007). Design features of an e-mentoring system for the health professions: Choosing to learn in partnership. Proceedings from $24^{\text {th }}$ Ascilite Conference, 2-4 December, Singapore.

Stokes, P., Garrett-Harris, R., \& Hunt, K. (2003). An evaluation of electronic mentoring (e-mentoring). Presented at the $10^{\text {th }}$ European Mentoring and Coaching Conference, 20-21 November, Cambridge, United Kingdom.

Williams, S., Sunderman, J., \& Kim, J. (2012). E-mentoring in an online course: benefits and challenges to e-mentors. International Journal of Evidence Based Coaching and Monitoring, 10(1), 109123. Retrieved from https://radar.brookes.ac.uk/radar/items/5a23e628-e881-48df-8eb37d0397934c0e/1/.

Williams, S. L., \& Kim, J. H. (2011). E-mentoring in online course projects: Description of an ementoring scheme. International Journal of Evidence Based Coaching and Mentoring, 9(2), 8095. Retrieved from http://ijebcm.brookes.ac.uk/documents/vol09issue2-paper-06.pdf.

Wong, A., \& Premkumar, K. (2007). An introduction to mentoring principles, processes and strategies for facilitating mentoring relationships at a distance. Retrieved from http://www.usask.ca/gmcte/drupal/?q=resources.

Wood, A. J. (2014). Tapping into internet resources: An e-mentoring option. A Capstone project submitted in partial fulfilment of the requirements for the Master of Science Degree. USA: Winona State University.

Zikmund, W. G., Babin, B. J., Carr, J. C., \& Griffen, M. (2009). Business research methods. $8^{\text {th }}$ edition. Kentucky: South-Western.

\section{Corresponding Author}

Dr. Nadine Oosthuizen, Nelson Mandela University, South Africa

Email: Nadine.oosthuizen@mandela.ac.za 